\title{
Modeling Vegetation Lifeforms Abundance based on Epigeal Termitaria Physiography and Altitude in Tropical Savannah of Katolo Sub-Location, Kisumu County
}

\author{
Wyclife Agumba Oluoch ${ }^{1 *}$, Boniface Oluoch Oindo ${ }^{2}$, Paul Abuom² \\ ${ }^{1}$ Department of Geography and Natural Resource Management, School of Environment and Earth Sciences, Maseno University, \\ Kisumu, Kenya \\ ${ }^{2}$ Department of Environmental Science, School of Environment and Earth Sciences, Maseno University, Kisumu, Kenya \\ Email: *wyclifeoluoch@gmail.com
}

How to cite this paper: Oluoch, W.A., Oindo, B.O. and Abuom, P. (2017) Modeling Vegetation Lifeforms Abundance based on Epigeal Termitaria Physiography and Altitude in Tropical Savannah of Katolo Sub-Location, Kisumu County. Journal of Geoscience and Environment Protection, 5, 22-31.

https://doi.org/10.4236/gep.2017.510003

Received: September 7, 2017

Accepted: October 15, 2017

Published: October 18, 2017

Copyright $\odot 2017$ by authors and Scientific Research Publishing Inc. This work is licensed under the Creative Commons Attribution International License (CC BY 4.0).

http://creativecommons.org/licenses/by/4.0/

\begin{abstract}
Termite mounds are major sites of functional heterogeneity in the tropical ecosystems globally; through their prodigious influence on vegetation and soil perturbation. They aid soil aeration, water infiltration and catabolism of vegetative matter into nutrient rich humus. There is no documentation of a model for prediction of vegetation lifeforms with respect to mound basal radii, heights and altitude. Objective of this study was therefore to develop a model for rapid prediction of vegetation lifeforms (trees, shrubs, lianas and grass) abundance based on physiography (basal radii and heights) and altitude of the termite mounds. Study population of the mounds was unknown. Cross sectional research design was used. Saturated sampling was done where sixty accessible termite mounds were studied. Both basal radii and heights of termite mounds were measured using $50 \mathrm{~m}$ tape measure or hand-held inclinometer. Altitude data were captured by hand-held Global Positioning System (GPS). Trees, shrubs and lianas were identified visually and counted on the mounds while grass abundance was estimated using $0.3 \mathrm{~m}$ by $0.3 \mathrm{~m}$ quadrat on every termitarium. Multiple Linear Regressions were done to model vegetation lifeforms abundance based on termite mound basal radius, height and altitude. Results indicated that predicted MLR significantly ( $\mathrm{p} \leq 0.05)$ predicted trees, shrubs and lianas but not grass abundance. Predicted trees abundance $=-89.2587+10.46157($ radius $(\mathrm{m}))-4.96989($ height $(\mathrm{m}))+0.074074$ (altitude $(\mathrm{m})$ ), predicted shrubs abundance $=19.26065+6.780626$ (radius (m)) -6.09157 (height (m)) -0.00822 (altitude (m)) and predicted lianas abundance $=-24.9345+5.881659$ (radius $(\mathrm{m}))-0.68423$ (height $(\mathrm{m}))+$ 0.020729 (altitude $(\mathrm{m})$ ). This study demonstrated significant effect of termite
\end{abstract}


mound physiography on vegetation lifeforms abundance as well as developed a model for rapid prediction of their abundance on termite mounds.

\section{Keywords}

Modeling, Termite Mounds, Vegetation Lifeforms Abundance, Tropical Savannah

\section{Introduction}

Multiple linear regressions is a statistical tool for understanding relationship between a dependent variable and one or more independent variables [1]-[6]. Normally, regression model is given in the form in Equation (1) below:

$$
Y=\beta_{0}+\beta_{1} X_{1}+\beta_{2} X_{2}+\cdots+\beta_{m} X_{m}+\varepsilon
$$

where $Y$ represent the dependent variable; $X_{1}, \cdots, X_{m}$ represent the several independent variables; $\beta_{0}, \cdots, \beta_{m}$ represent the regression coefficients and; $\varepsilon$ represent the random error (residuals).

Regression model has been used in studies of termite mounds including explanation of termite mounds occurrence with canopy cover, distance from forest edge and logging and stump removal as multiple explanatory variables in Nepal [7]. In West Africa, a model was developed to predict yield of sorghum with respect to density of termite mounds, labor and acreage of sorghum fields as predictor variables [8]. Earlier, in another study, Cox regression models were used to determine mortality rates of termites as a function of time and dose rates of fungal isolates [9].

Multiple linear regression models were run elsewhere to determine the number of termite taxa as a function of latitude, altitude, mean annual precipitation and Simpson index of vascular plants [10]. Clay content of mound soils was determined using regression model with Aluminium, Natrium, Kalium, Magnesium, Phosphorus, Titanium, Iron and Manganese as the independent variables [10]. Results showed up to $78 \%$ of overall variation in the clay content being explained by $\mathrm{Al}, \mathrm{Mg}, \mathrm{Ti}, \mathrm{Fe}$ and $\mathrm{Mn}$ in an equation as shown in Equation (2) below:

$$
\% \text { Clay }=-7.0+6.4 \mathrm{Al}-0.8 \mathrm{Mg}-11.0 \mathrm{Ti}+1.3 \mathrm{Fe}-3.9 \mathrm{Mn} \text {. }
$$

In order to explain the moisture retention of soils with distance from termite mound, a regression model was developed which showed declining moisture retention ability of soil with distance from the base of termite mound [11] as given in Equation (3) below:

$$
Y=21.219 x^{-0.206}, R^{2}=0.871
$$

Global and regional studies provide indication that regression modeling can be a great effort in supporting prediction of dependent variable values based on several independent variables. Using a single independent variable may not give 
satisfactory results especially in ecological studies where a dependent variable may have several independent variables.

Accordingly, there has been no attempt in literature to model vegetation lifeforms on termite mounds using various physiographic characteristics of the mounds as predictor variables. Physiography of a termite mound (basal radius and height) as well as its altitudinal location has been surveyed in several studies but none has attempted to use them in explaining abundance of vegetation lifeforms. It would be quite economical to assess abundance of vegetation lifeforms based on variables that can be easily and rapidly measures such as basal radii and heights of termite mounds. This study therefore developed a model to predict vegetation lifeforms abundance on termite mound by relying on physiography of the mounds (basal radius and height) as well as altitudinal location. It is envisaged that this will make it possible to conduct rapid assessment of vegetation lifeforms abundance in tropical savannah ecosystem.

\section{Materials and Methods}

\subsection{Study Area and Data}

\subsubsection{Study Area}

Katolo Sub-Location is located within Kano Plains centered at latitude $0^{\circ} 14^{\prime} \mathrm{S}$ and longitude $35^{\circ} 00^{\prime} \mathrm{E}$ with elevation ranging from $1175 \mathrm{~m}$ on the lowest Western end to $1341 \mathrm{~m}$ on top of Orucho hills to the Eastern end bordering Kapsarok Sub-Location of Rift Valley Province (Figure 1).

The area receives long rains in the month of May and short rains normally come in September [12]. Mean annual rainfall in the area is $1200 \mathrm{~mm}$ [13] with mean annual temperature being $31^{\circ} \mathrm{C}$ [14]. The area comprises of predominantly black cotton soils with moderate fertility and poor drainage [15] classified as vertisols and crack during drought and flood in rainy seasons [14]. Some parts of the study area have sandy loam soils derived from igneous rocks especially to the East that borders the Rift Valley Province [14].

Livestock rearing (cattle, sheep and goats) and crop farming (maize, sorghum, beans and assorted local vegetables) dominate the area [14]. The area supports a large rural population (75 percent) and the stage of economic growth is undermined by high absolute poverty levels, deteriorating infrastructure and the HIV pandemic [16] [17]. Katolo Sub-Location of Nyando Sub-County, Kisumu County is a savanna grassland area that lies in the Eastern part of large lowland surrounding the Nyanza Gulf, much of it being in Kano Plains [18]. Even though the topography is generally flat, there are several scattered termite mounds that appear as "topographic accidents".

Being a plain, many studies in this area have focused on rainfall run-off modeling [19], gully erosion along the river banks [18] and education standards [12]. However, epigeal termitaria appear to display richer assemblages of flora that look patchy from one termitarium to the other in the study area; usually more visible during the dry season where they stand out as greener patches than their 


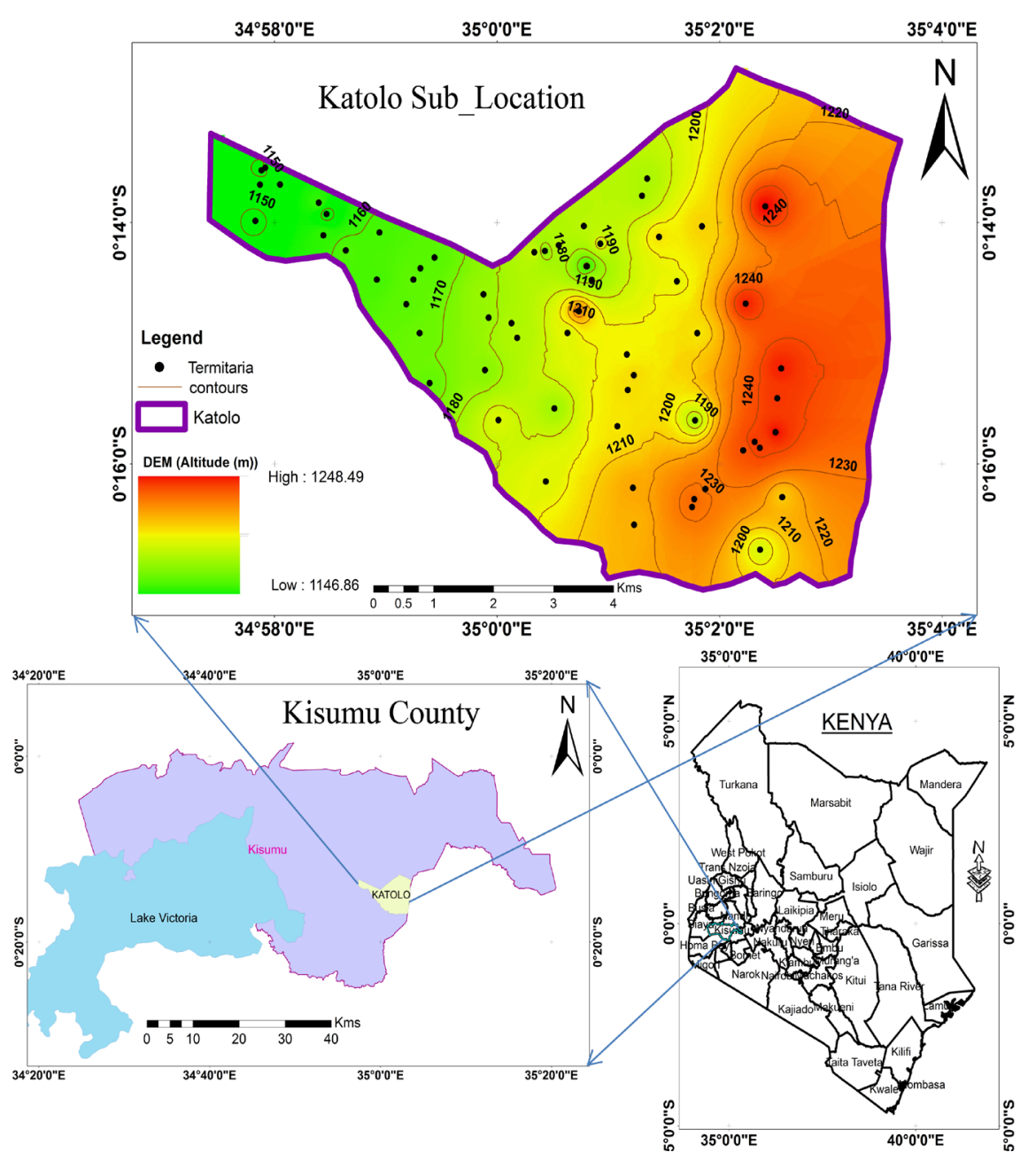

Figure 1. Study Area.

savannah surroundings (O. Wyclife, personal communication, March 4, 2016); yet lack in documentation so far. No studies have been done on the effects of termitaria physiography on vegetation lifeforms abundance in the area, yet.

\subsubsection{Sampling and Data}

A cross-sectional descriptive research design was used in this study. The design was employed because it allowed for studying of the termite mounds in their natural state (in situ). The design allowed for future detailed investigation on key variables studied and gave opportunity to gather in-depth information about the variables. This was an appropriate method for this study since the units of analysis; termite mounds and vegetation lifeforms were already in the study area and could be studied within a short span of time.

The actual data about the number of termite mounds in the study area was not in existence. A sample size of 60 mounds was used after reviewing literature on appropriate sample sizes that have been used by other researchers in studying termitaria elsewhere. Reference [20] in their study on ventilation of termite mounds in Canberra Australia used a range of sample sizes; 72, 68, 60 and 54 
based on the variables of interest for their study. Reference [21] used only 21 termite mounds and matrix plots to investigate physico-chemical properties of termite mound soils. On the other hand, [22] used 56 termite mounds to study medicinal uses of plant species found on termitaria in the Pendjari biosphere reserve.

Reference [10] relied on 26 mounds to investigate heterogeneity by termite mounds in Namibia. Reference [23] used 20 termite mounds to sample soils for determining response of rice and beans on their fertilization with mound soils as sources of NPK fertilizers. In their analysis of the phytodiversity on termite mounds in Northern Benin, [24] used 57 termite mounds. Reference [25] used 98 termite mounds and 43 matrix plots to assess woody plants assemblages on them.

In this study, we used a total of 60 termite mounds which were arrived at randomly provided they fell within the study area of Katolo Sub-location. Starting termite mound for sampling was chosen randomly based on the convenience to the researchers and its location within the area of study following the work of [26]. Captured Global Positioning System (GPS) coordinates helped in avoiding repetitive sampling of the mounds.

Data used in this study were obtained via primary data collection methods between December, 2016 and March, 2017. Primary data collection methods adopted were observation, measurement, counting and recording. These methods were appropriate for the data collection because the data to be collected could be obtained by measurement (height, radius and altitude) and counting (trees, shrubs, lianas and grass).

Mound basal radius, $r_{b}$, was estimated from the circumference of the base of the mound, $c_{b}$. A $50 \mathrm{~m}$ tape measure was wound round the base of every termite mound to find out the circumference following the formula adopted from [27], basal radius ( $m$ ) was obtained as follows:

$$
r_{b}=c_{b} / 2 \pi
$$

A $50 \mathrm{~m}$ tape measure was used to quantify termite mound height (m) by holding it vertically adjacent to the termite mound walls and vertical rise observed by the researcher. In case where the termite mound was taller than the researcher, inclinometer was used alongside simple trigonometric ratios to determine exact mound heights [27]:

$$
H=h+d \tan \theta
$$

where $\mathrm{H}$ is the termite mound height $(\mathrm{m}), \mathrm{h}$ is the height of the observer $(\mathrm{m}), \mathrm{d}$ is the distance from the centre of the termite mound to observer $(\mathrm{m})$ and $\theta$ is the angle of elevation (in degrees) of the top of the mound from the horizontal line of sight of the observer. Altitude of the termite mounds was determined using hand-held Global Positioning System (GPS) and given in metres.

Trees growing on-mound were regarded as woody vegetation lifeforms with diameter at the base (10 $\mathrm{cm}$ above the mound) greater than $6 \mathrm{~cm}$ as determined 
by sliding Vernier caliper and have heights above $3 \mathrm{~m}$ (determined by inclinometer) as applied elsewhere by [28]. These were counted by two observers and actual population obtained following [29] sampling approach by two observers. Shrubs growing on and off-mound plots were woody plants below $3 \mathrm{~m}$ in height (determined by inclinometer) and have diameter less than $6 \mathrm{~cm}$ at $10 \mathrm{~cm}$ above the ground as determined by sliding Vernier caliper [28]. Counting was done as in the case of trees and [29] sampling approach applied. Lianas were determined as twining or climbing plants with relatively long stems which can be woody or herbaceous according to USDA, Growth Habits Codes and Definitions; https://plants.usda.gov/growth_habits_def.html (Accessed on 10th October, 2016). Individual counting was done on termite mounds.

Due to labor intensity of counting individual grass throughout the mound or off-mound plots, a $0.3 \mathrm{~m} \times 0.3 \mathrm{~m}$ quadrat was used to estimate the population of grass on every termite mound. Adoption of quadrat method followed the works of [30] $(0.5 \mathrm{~m} \times 0.5 \mathrm{~m})$, [26] $(0.75 \mathrm{~m} \times 0.75 \mathrm{~m})$, [31] $(1 \mathrm{~m} \times 1 \mathrm{~m})$, [32] $(3 \mathrm{~m} \times 3$ $\mathrm{m})$, [33] $(10 \mathrm{~m} \times 10 \mathrm{~m})$, [25] $(2 \mathrm{~m} \times 50 \mathrm{~m})$ (transect) and [27] $(185 \mathrm{~m} \times 185 \mathrm{~m})$ (transect). The quadrat was thrown onto every termite mound randomly and individual grass within the quadrat was/were counted. That was done thrice on every termite mound to obtain average number of grass per termite mound after multiplying the average quadrat value by the area of the whole mound and dividing by the quadrat area.

\subsection{Analytical Methods}

Four multiple linear regression models with vegetation lifeforms (trees, shrubs, lianas and grass) abundance as dependent variables and termite mounds physiography (basal radius, height and altitude) as independent variables were developed in Statistical Package for Social Sciences (SPSS) (Version 16.0 Release 16.0.0) programme. Independent variables were first tested for collinearity and were noted to have no significant correlation. Models gave the best predictions that were tested for significance at $\mathrm{p} \leq 0.05$.

\section{Results and Discussion}

Three independent variables (termite mound basal radius, height and altitudinal location of termite mound) were used to develop a model. Initially a test for collinearity was done among the variables. The test for collinearity was meant to leave out independent variables that were significantly correlated. Test results showed that none of the variables were significantly $(\mathrm{p} \leq 0.05)$ correlated with each other (Table 1) hence all were used to develop a predictor model for the various vegetation lifeforms abundance.

A multiple regression model to predict trees abundance on termite mounds was developed at $95 \%$ confidence level with $\mathrm{F}(3,57)=94.77, \mathrm{p}=0.000)$ with adjusted $\mathrm{r}^{2}$ of $82.66 \%$. The relationship gave the following regression equation (Equation (6)): 
Table 1. Spearman's test for collinearity results indicating non-significance among the independent variables.

\begin{tabular}{cccc}
\hline & Basal radii & Heights & Altitude \\
\hline Basal radii & 1.00 & $\mathrm{NS}^{\mathrm{a}}$ & $\mathrm{NS}^{\mathrm{a}}$ \\
Heights & 0.135 & 1.00 & $\mathrm{NS}^{\mathrm{a}}$ \\
Altitude & 0.153 & -0.023 & 1.00 \\
\hline
\end{tabular}

$$
T_{a}=-89.2587+10.46157 r-4.96989 h+0.074074 a
$$

where $T_{a}$ is Tree abundance, $r$ is basal radius $(\mathrm{m}), h$ is termite mound height and $a$ is altitude $(\mathrm{m})$.

On the other hand, shrubs abundance on termite mounds could also be modeled with a statistically significant $(\mathrm{p} \leq 0.05)$ linear relationship with physiographic attributes of termite mounds and altitude in a multiple regression model $(\mathrm{F}(3,57)=20.21, \mathrm{p}=0.000)$ with adjusted $\mathrm{r}^{2}$ of $49.41 \%$. The relationship gave the following regression equation (Equation (7)):

$$
S_{a}=19.26065+6.780626 r-6.09157 h-0.00822 a
$$

where $S_{a}$ is Shrubs abundance, $r$ is basal radius $(\mathrm{m}), h$ is termite mound height and $a$ is altitude $(\mathrm{m})$.

Lianas abundance was also significantly $(\mathrm{p} \leq 0.05)$ explained by variation in termite mound physiographic attributes and altitude $(\mathrm{F}(3,56)=56.18, \mathrm{p}=0.000)$ and $r^{2}=73.72 \%$. The regression model equation which could help to estimate lianas abundance within the study area was found to be:

$$
L_{a}=-24.9345+5.881659 r-0.68423 h+0.020729 a
$$

where $L_{a}$ is Lianas abundance, $r$ is basal radius $(\mathrm{m}), h$ is termite mound height and $a$ is altitude $(\mathrm{m})$.

The last vegetation life form investigated was grass abundance which did not show significant response to variation in termite mound physiographic attributes and altitude $(\mathrm{F}(3,56)=0.47, \mathrm{p}=0.706)$ with an $\mathrm{r} 2=-2.78 \%$. An equation to support prediction of abundance of grass on the termite mounds studied was:

$$
G_{a}=676.4303+114.0194 r-45.1003 h+0.182634 a
$$

where $G_{a}$ is Grass abundance, $r$ is basal radius $(\mathrm{m}), h$ is termite mound height and $a$ is altitude $(\mathrm{m})$.

The significant $(\mathrm{p}<0.05)$ multiple regression equations obtained could help in predicting abundance of vegetation lifeforms in tropical savannah ecosystems such as was the case with Katolo Sub-Location in Kisumu County.

This application of multiple linear regression models to predict vegetation lifeforms abundance borrowed from the work by [7] in Nepal who modeled termite mounds occurrence based on canopy cover, distance from forest edge, logging and stump removal. The concept equally followed the study by [8] who 
modelled sorghum yield based on termite mounds density, labor and acreage as predictor variables. Mortality rates of termite mounds had also been presented elsewhere [9] to depend on time and dose of fungal inoculation. Reference [10] gave a multiple regression model of predicting termite mound taxa based on altitude, latitude, precipitation and Simpson's index of vascular plants.

This study has however gave a new model to be easily tested and adopted in rapid assessment of various vegetation lifeforms within tropical savannah ecosystems based on basal radius, heights and altitudinal location of termite mounds.

\section{Conclusion \& Recommendation}

Based on the findings of this study, it was concluded that Multiple Regression Model could be a rapid option for determining abundance of vegetation lifeforms based on physiography of the termite mounds. Trees, shrubs and lianas vegetation lifeforms could be significantly predicted using basal radii, heights and altitude of the mound. However, grass abundance could not be significantly predicted using the model. The study was limited to dry season and it would be important to conduct similar study across seasons in order to arrive at better comparative results. It is recommended that other variables such as soil physical-chemical parameters of termite mounds be investigated in the study area to support development of a robust model for prediction of vegetation lifeforms abundance, especially grass.

\section{References}

[1] Basu, S. and Lokesh, K.S. (2014) Application of Multiple Linear Regression and MANOVA to Evaluate Health Impacts Due to Chnaging River Water Quality. Applied Mathematics, 5, 799-807. https://doi.org/10.4236/am.2014.55076

[2] Pathak, H. (2012) Evaluation of Ground Water Quality Using Multiple Linear Regression and Mathematical Equation Modeling. Annals of the University of Oradea-Geography Series, 2, 304-307.

[3] Pathak, H. (2013) Water Quality Studies of Two Rivers at Bundelkhand Region, MP, India: A Case Study. U.P.B Science Bulletin, Series B, 75, 81-90.

[4] Mustapha, A. and Abdu, A. (2012) Application of Principal Component Analysis \& Multiple Regression Models in Surface Water Quality Assessment. Journal of Environment and Earth Sciences, 2, 16-23,.

[5] Mustapha, A. and Aris, A.Z. (2012) Multivariate Statistical and Environmental Modeling of Heavy Metals Pollution by Industries. Polish Journal of Environmental Studies, 21, 1359-1367.

[6] Koklu, R., Sengorur, B. and Topal, B. (2010) wATER qUALITY aSSESSMENT Using Multivariate Statistical Methods-A Case Study: Melen River System (Turkey). Water Resource Management, 24, 959-978. https://doi.org/10.1007/s11269-009-9481-7

[7] Axelsson, E.P. and Andersson, J. (2012) A Case Study of Termite Mound Occurrence in Relation to Forest Edges and Canopy Cover within the Brandabhar Forest Corridor in Nepal. International Journal of Biodiversity and Conservation, 4, 
633-641.

[8] Ogoudedji, G.P.C., Nuppenau, E.-A. and Korb, J. (2010) The Role of Ecosystem Services of Termites (Macrotermes bellicosus) in Agriculture in Pendjari Region (Benin). Conference on International Research on Food Security, Natural Resource and Rural Development, Zurich, 14-16 September 2010.

[9] Abebe, H. (2002) Potential Entomopathogenic Fungi for the Control of Macrotermes Subhyalinus (Isoptera: Termitidae). Ph.D. Thesis, Hannover.

[10] Grohmann, C. (2010) Termite Mediated Heterogeneity of Soil and Vegetation Patterns in a Semi-Arid Savanna Ecosystem in Namibia. Julius Maximilian University of Wuzburg, Wuzburg.

[11] Sileshi, G.W., Arshad, M.A., Konate, S. and Nkunika, P.O.Y. (2010) Termite-Induced Heterogeneity in African Savanna Vegetation: Mechanisms and Patterns. Journal of Vegetation Sciences, 21, 923-937. https://doi.org/10.1111/j.1654-1103.2010.01197.x

[12] Okuom, H.A., Simatwa, E.M.W., Olel, M.A. and Wichenje, M.K. (2012) Assessment of Factors That Contribute to Repetition and Dropout of Pupils in Primary School in Flood Prone Areas of Nyando District, Kenya. International Research Journals, 3, 190-201.

[13] Yamane, Y., Asanuma, S. and Umenaura, K. (2015) Influence of Livestock Farming on Vegetation in a Degraded Soil Area on the East Coast of Lake Victoria in Western Kenya: A Case Study of Jimo East Sub-Location in Nyando Sub-County. Journal of Environmental Protection, 6, 824-836. https://doi.org/10.4236/jep.2015.68075

[14] Nyasimi, M., Butler, L.M., Burras, L., Ilahiane, H., Schultz, R. and Flora, J. (2007) Differentiating Livelihood Strategies among the Luo and Kipsigis People in Western Kenya. Agrarian/Non-Agrarian Livelihood Continuum, 11, 43-57.

[15] Government of Kenya (2004) Food Security District Profile. GoK, Nairobi.

[16] Swallow, B., Onyango, L. and Meinzen-Dick, R. (2003) Catchment Property Rights and the Case of Kenya's Nyando Basin. Watershed Management and Sustainable Mountain Development, Working Paper Number 8, Rome, 8-10 October 2003.

[17] JICA (2007) The Development Study for Regional Development Programme in Nyando and Homa-Bay Districts in the Republic of Kenya. International Corporation Agency, Tokyo.

[18] KSS (1990) The Environment and Soil Profiles Characterization of Some Gully Sites within Winam Gulf Soil and Water Conservation Project Area (Kisumu District). Republic of Kenya.

[19] Rwigi, S.K., Opere, A.O. and Mutua, F.M. (2010) Comparative Case Study of Rainfall-Runoff Models over the Nyando River Basin. The University of Nairobi, Nairobi.

[20] Korb, J. and Linsenmair, K.E. (1999) Ventilation of Termite Mounds: New Results Require a New Model. Behavioral Ecology, 486-494.

[21] Ackerman, I.L., Wenceslau, G.T., Susan, J.R., Johannes, L. and Erick, C.M. (2007) The Impact of Mound-Building Termites on Surface Soil Properties in a Secondary Forest of Central Amazonia. Applied Soil Ecology, 37, 267-276.

[22] Dossou-Yovo, H.O., Vodouhe, F.G. and Sinsin, B. (2010) Assessment of the Medicinal Uses of Plant Species Found on Termitaria in the Pendjari Biosphere Reserve in Benin. Journal of Medicinal Plant Research, 8, 368-377.

[23] Fageria, N.K. and Baligar, V.C. (2011) Properties of Termite Mound Soils and Responses of Rice and Bean to Nitrogen, Phosphorus, and Potassium Fertilization on 
Such Soil. Communications in Soil Science and Analysis, 35, 2097-2109. https://doi.org/10.1081/LCSS-200028919

[24] Kirchmair, I., Schmidt, M., Zizka, G., Erpenbach, A. and Hahn, K. (2012) Biodiversity Islands in the Savanna-Analysis of the Phytodiversity on Termite Mounds in Northern Benin. Flora et Vegetatio Sudano-Sambesica, 15, 3-14.

[25] Joseph, G.S., Seymour, C.L., Cumming, G.S., Cumming, D.H.M. and Mahlangu, Z. (2012) Termite Mounds as Islands: Woody Plant Assemblages Relative to Termitarium Size and Soil Properties. Journal of Vegetation Science, 24, 702-711.

[26] Beaudrot, L., Du, Y., Rahman, K.A., Rejmanek, M. and Harrison, R.D. (2011) Do Epigeal Termite Mounds Increase the Diversity of Plant Habitats in a Tropical Rain Forest in Peninsular Malaysia? PLoS ONE, 6, e19777. https://doi.org/10.1371/journal.pone.0019777

[27] Scott, T.J. (2000) Architecture and Morphogenesis in the Mound of Macrotermes nichaelseni (Sjostedt) (Isoptera: Termitidae, Macrotermitinae) in Northern Namibia. Cimbebasia, 16, 143-175.

[28] Moe, S.R., Mobaek, R. and Narmo, A.K. (2009) Mound Building Termites Contribute to Savanna Vegetation Heterogeneity. Plant Ecology, 202, 31-40. https://doi.org/10.1007/s11258-009-9575-6

[29] Lincoln, F.C. (1930) Calculating Waterfowl Abundance on the Basis of Banding Returns. U.S. Department of Agriculture.

[30] Kaspari, M., Clay, N.A., Donoso, D.A. and Yanoviak, S.P. (2014) Sodium Fertilization Increases Termites and Enhances Decomposition in Amazonian Forest. Cology, 95, 795-800.

[31] Khan, W., Khan, S.M. and Ahmed, H. (2015) Altitudinal Variation in Plant Species Richness and Diversity at Thandiani Sub Forests Division, Abbottabad, Pakistan. Journal of Biodiversity and Environmental Sciences, 7, 46-53.

[32] Ekundayo, E.O. and Orhue, E.R. (2011) Physical and Chemical Properties of Termite Mounds and Surrounding Soil as Influenced by Land Use in the Niger Delta Region of Nigeria. Migerian Journal of Soil and Environmental Research, 9, 53-58.

[33] Yamashina, C. (2010) Interactions between Termite Mounds, Trees, and the Zemba People in the Mopane Savanna in Northwestern Namibia. African Study Monograph, 40, 115-128. 